Article

\title{
Giant Fluorite Mineralization in Central Mexico by Means of Exceptionally Low Salinity Fluids: An Unusual Style among MVT Deposits
}

\author{
Eduardo González-Partida ${ }^{1, *}$, Antoni Camprubí ${ }^{2}$, Alejandro Carrillo-Chávez ${ }^{1}$, \\ Erik H. Díaz-Carreño ${ }^{3}$, Luis E. González-Ruiz ${ }^{4}$, José L. Farfán-Panamá ${ }^{5}$, \\ Edith Cienfuegos-Alvarado $^{2,6}$, Pedro Morales-Puente ${ }^{2,6}$ and Juan T. Vázquez-Ramírez ${ }^{1}$ \\ 1 Centro de Geociencias, Universidad Nacional Autónoma de México, Blvd. Juriquilla 3001, \\ Juriquilla 76230, Querétaro, Mexico; ambiente@geociencias.unam.mx (A.C.-C.); \\ jtvazquez@geociencias.unam.mx (J.T.V.-R.) \\ 2 Instituto de Geología, Universidad Nacional Autónoma de México. Ciudad Universitaria, \\ Coyoacán, CDMX 04510, Mexico; camprubitaga@gmail.com (A.C.); edithca@unam.mx (E.C.-A.); \\ mopuente@unam.mx (P.M.-P.) \\ 3 Posgrado en Ciencias de la Tierra, Universidad Nacional Autónoma de México, Blvd. Juriquilla 3001, \\ Juriquilla 76230, Querétaro, Mexico; erikhdc@gmail.com \\ 4 Geología Minería y Consultoría, Cipreses 1904, Jurica 76230, Querétaro, Mexico; 1_e_g_r@hotmail.com \\ 5 Unidad Académica de Ciencias de la Tierra, Universidad Autónoma de Guerrero, \\ Ex Hacienda de San Juan Bautista, Taxco el Viejo 40323, Guerrero, Mexico; joself71@hotmail.com \\ 6 Laboratorio Nacional de Geoquímica y Mineralogía (LANGEM), Ciudad Universitaria, \\ Coyoacán, CDMX 04510, Mexico \\ * Correspondence: egp@geociencias.unam.mx
}

Received: 27 November 2018; Accepted: 26 December 2018; Published: 11 January 2019

\begin{abstract}
The origin of the mineralization at the world-class Las Cuevas (the largest single fluorite deposit in the world) has been historically disputed, essentially between skarn-related and Mississippi Valley Type (MVT) models. A systematic study of fluid inclusions in these deposits revealed that they were formed by low temperature $\left(49\right.$ to $\left.177^{\circ} \mathrm{C}\right)$ and low salinity (0 to $1.9 \mathrm{wt} \% \mathrm{NaCl}$ equiv) fluids. The obtained $\delta^{13} \mathrm{C}$ (between -2.39 and $0.20 \%$ VPDB) and $\delta^{18} \mathrm{O}$ (between -14.03 and $-7.37 \%$ VPDB) data from local host limestones agreed with regionally representative values in the literature. The obtained $\delta^{13} \mathrm{C}$ (between -15.60 and $-12.99 \%$ VPDB) and $\delta^{18} \mathrm{O}$ (between -5.56 and $-1.84 \%$ VPDB) data from hydrothermal calcite associated with fluorite mineralization indicated that the isotopic composition of hydrothermal fluids initially reflected buffering by the host rocks, and then recorded the interaction between meteoric water and basinal brines. It is likely that such processes occurred with concurrent maturation of organic matter, and that the obtained compositions may also have recorded a thermal effect on the local limestones. The basinal brines with which the formation of these deposits was associated were massively diluted by deeply evolved meteoric water, thus making a significant fluorine input by basinal brines unlikely. Fluorine would have been provided by local groundwater through its interaction with Oligocene topaz rhyolites and other F-rich volcanic and hypabyssal rocks. Such a possibility is supported by present-day groundwater, which presents a regional endemic case of fluorosis. The precipitation of fluorite is possible at low temperatures (at which the solubility of this mineral is very low) by means of chemical reactions and physical interactions among very diluted F-poor basinal brines, F-rich groundwater, and host carbonate rocks. The latter systematically experienced hydrothermal karstification, which would have provided $\mathrm{Ca}^{2+}$ for reaction with $\mathrm{F}^{-}$and resulted in the precipitation of fluorite. This scenario stands for a depositional model that recalls those proposed for MVT and associated industrial mineral deposits, but is distinct from common models with regard to the primal source for fluorine and the extremely low salinities of inclusion fluids.
\end{abstract}


Keywords: fluorite; MVT; fluid inclusions; $\delta^{18} \mathrm{O} ; \delta^{13} \mathrm{C}$; halogen geochemistry; meteoric water; diluted basinal brines; fluid mixing; F-rich groundwater; hydrothermal karst; fault-controlled

\section{Introduction}

Mexico is a worldwide leader in the production of some nonmetallic minerals such as celestine, barite, and fluorite [1,2]. The production of fluorite in Mexico is normally second only to that of China at an international level [3]. San Luis Potosí is the leading Mexican state in fluorite production. Such wealth comes from the Las Cuevas deposit, which is widely regarded as the largest individual producer of fluorite in the world [2-4], both acid- and metallurgic-grade. It forms a prominent cluster of deposits with the Río Verde area (El Realito, El Refugio, and La Constancia deposits) between the states of San Luis Potosí and Guanajuato (Figure 1). The origin of such fluorite deposits has been intermittently debated, between models that formulate a hydrothermal origin sustained by local magmatism [5,6] and a scenario similar to a Mississippi Valley Type (MVT) model [2,4] in which meteoric water would have had a paramount role as an agent for mineralization. However, in spite of the massive size and world-class status of the Las Cuevas deposit, no depositional model has been soundly established so far.

A recent wealth of information [1,2,4,7-11] has allowed for the determination that ore-forming fluids of many $\mathrm{Zn}-\mathrm{Pb}$, fluorite, celestine, and barite deposits that occur across formerly marginal basins of the paleo-Gulf of Mexico are compatible with basinal brines with diverse degrees of interaction with meteoric water or evaporites and, therefore, can be generically ascribed to an MVT model. Such is also the case with red-bed-hosted epigenetic copper deposits $[1,2,9,11,12]$. The deposits related to such models extend across a broad region of eastern and northeastern Mexico, Texas, and into the Río Grande Rift in the south-central U.S. [2] (their Figure 12). The main mineralized regions in Mexico are, NW to SE, (A) the Chihuahua Trough province, (B) the provinces of northeastern Mexico (including the Sabinas, La Popa, and Parras basins), and (C) the San Luis-Valles province (Figure 1). The studied deposits in this paper are located on the southwestern border of the Valles-San Luis Potosí Platform, which developed on one of the most prominent basement highs that resulted in the horst-and-graben configuration that rimmed the paleo-Gulf of Mexico after the breakup of Pangea. San Luis-Valles province includes epigenetic carbonate rock-hosted MVT-like $\mathrm{Zn}-\mathrm{Pb}$ and associated celestine, barite, and fluorite deposits, sulfur deposits due to bacteriogenic or thermogenic sulfate reduction processes in salt diapir caps, and red-bed-hosted copper deposits (Reference [2], and references therein).

Previous works on the "E" and "G" orebodies at Las Cuevas $[4,6]$ have provided (A) fluid inclusion data that indicated very dilute and low-temperature mineralizing fluids (salinity mostly $<0.2 \mathrm{wt} \%$ $\mathrm{NaCl}$ equiv and a temperature of homogenization $<130{ }^{\circ} \mathrm{C}$ ) that are compatible with heated meteoric water, and (B) isotopic data that are suggestive of organic matter maturation and decarbonation processes during the formation of the deposits. In this work, we provide new data on the morphology of ore bodies, the microthermometry of fluid inclusions, oxygen and carbon isotope geochemistry, with the aim of contributing to the definition of a likely model of formation for the ensemble of fluorite deposits in the Las Cuevas and Río Verde mineralized areas. 


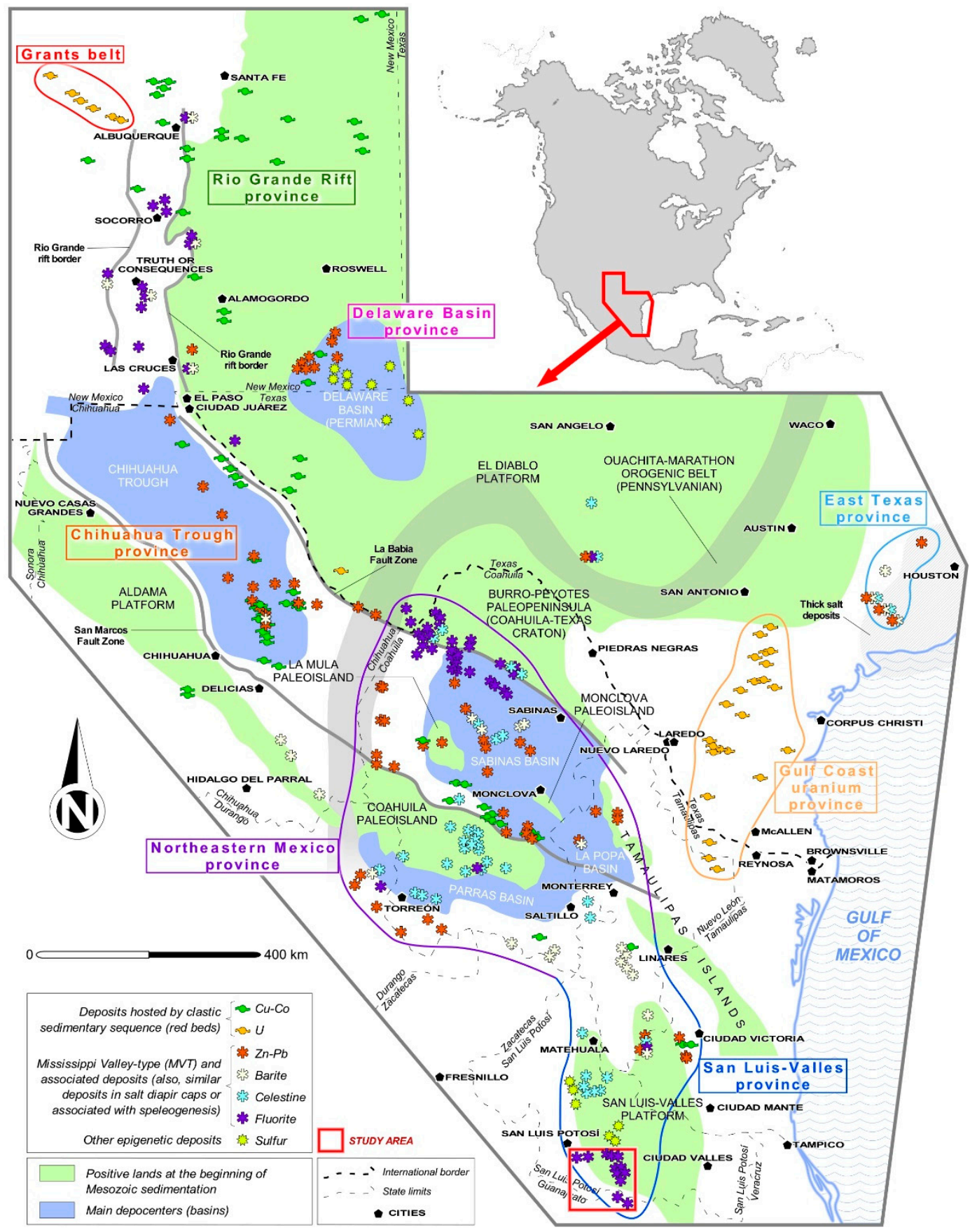

Figure 1. Distribution of epigenetic stratabound ore deposits of the sedimentary-diagenetic realm astride northeastern to central Mexico and the southern U.S. It encompasses the distinctive metallogenic provinces of (1) northeastern Mexico, (2) Chihuahua Trough, (3) San Luis-Valles, (4) Rio Grande Rift, (5) Gulf Coast, (6) Delaware Basin, (7) Grants Belt, and (8) East Texas. The latter represents some modern similar and analogous mineralization to Mississippi Valley Type (MVT) deposits in diapir caps and other occurrences. Recent occurrences of mineralization similar to MVT deposits are also included here. The most abundant featured types or styles of ore deposits are MVT and associated barite, celestine, and fluorite deposits; epigenetic metalliferous (Cu-Co-etc. and U) deposits hosted by clastic sequences, and speleogenetic sulfur deposits associated with diapir caps. Some sulfur thermogenic sulfate reduction-derived (TSR) deposits occur in Texistepec and Jáltipan in southern Veracruz (not shown in the map) and Guaxcamá in the San Luis-Valles platform. Modified from Reference [2]. The study region is framed in red. 


\section{Local Geology and Fluorite Deposits}

The Las Cuevas-Río Verde cluster of fluorite deposits (Las Cuevas, El Realito, La Constancia, and El Refugio mines; Figures 1 and 2) is located in the Álvarez range (Sierra de Álvarez), about $40 \mathrm{~km}$ east of the city of San Luis Potosí, on the southwestern limit of the Valles-San Luis Potosí Jurassic-Cretaceous carbonate platform (VSLPP) $[2,4,6,13-16]$. The carbonate sequences in the area correspond mostly to reef and platform facies that belong to the Albian-Cenomanian El Doctor and Abra formations [13-15], and they are topped by the Upper Cretaceous Soyatal Formation, which consists of shaly and limestone breccias [17-19] (Figure 2). The Cenozoic magmatism in the area occurs as Oligocene hypabyssal and volcanic rhyolites and dacites, and minor granodiorite [4-6] (Figure 2). Oligocene rhyolites in this region constitute a part of the San Luis Potosí Volcanic Field, and are typically highly evolved and fluorine-rich (topaz-bearing) rocks, hence the hydrothermal tin mineralization that is commonly associated with them [2,20-25].

This region is complex in structure, as it contains (A) compressive structures associated with tectonostratigraphic terranes accreted to the Oaxaquia subcontinental block, including the pre-Jurassic and Upper Cretaceous collision fronts [26], (B) extension structures associated with the opening of the paleo-Gulf of Mexico, in which the VSLPP platform represents a former horst in the pre-Jurassic basement $[2,13,14]$, and (C) successive reactivations of the above during the Cenozoic along the San Luis-Tepehuanes Fault Zone (SLTFZ) and associated faults around Mesa Central [22,23]. The SLFTZ and similar fault zones around Mesa Central have been recognized as effective channelways for the emplacement of magmas and ore deposits [2,22,23].

All the known fluorite bodies in the Las Cuevas cluster (seven of them, in the giant Las Cuevas deposit) are massive, almost monomineral, exclusively carbonate-hosted, epigenetic, fault-controlled, and mostly located along the fault contact between Oligocene rhyolites (dated at 30.9-30.5 Ma [5]) and the late Lower to early Upper Cretaceous carbonate sequences of the El Abra and Soyatal formations [4-6]. Hypabyssal Oligocene rocks are normally emplaced through NW-SE faults that were active during the emplacement of fluorite deposits, as demonstrated by the occurrence of argillized rhyolite fragments within the fluorite bodies [4-6], and were the conduits for their extrusive relatives. Most fluorite deposits developed funnel shapes, and are made of massive, semi-massive to slightly banded internal arrangements (noticeable by changes in color or texture), or collapse and fault breccias (with fragments of host limestones and Oligocene intrusive rocks), and cavities of many shapes and sizes in which fluorite may even show stalactitic growths. Breccias are mostly found rimming the fluorite bodies. The contact between the massive fluorite orebodies and the enclosing limestone is roughly gradual and reveals a progressive replacement of the carbonate rocks through a network of fluorite + calcite veins crosscutting a thin envelope of recrystallized and seldom-brecciated limestone developed around the fluorite bodies [4,27]. Both the size of the veins and the degree of recrystallization of the limestone gradually decrease from the massive fluorite bodies grading into the fresh limestone. All the mineralized bodies have been interpreted due to the filling of karst structures that underwent partial collapse, and it has been argued that karstic cavities were produced by hydrothermal fluids [4].

\subsection{Las Cuevas Mineralized Area}

Las Cuevas is a world-class fluorite deposit in which mining operations started during the 1950s. Fluorite is the sole mineral of economic interest in the mineralized bodies, attaining an average grade of $84 \%$ (between $50 \%$ and $98.5 \%$ ) with estimated reserves at $30 \mathrm{Mt}$ [28,29]: It is accompanied by calcite and quartz as the main gangue minerals, plus minor quantities of pyrite, arsenopyrite, sphalerite, barite, and galena (Figure 3). The individual mineralized bodies are generally irregular, and their sizes are quite variable: They range between 100 and $800 \mathrm{~m}$ in length, between 50 and $160 \mathrm{~m}$ in width, and between 200 and $500 \mathrm{~m}$ in depth in the "G" body (Figure 4), which is the largest one known to date in this district. Other mineralized bodies already exploited (" $\mathrm{A}$ ", " $\mathrm{B}$ ", " $\mathrm{C}$ ", " $\mathrm{D}$ ") are similar to the " $G$ " body, which is currently producing about 6000 tons daily through underground mining. The mineralization is emplaced within a collapse karst structure developed along a NW-SE striking 
regional fault (steeply dipping to the NE) between rhyolitic ignimbrites and massively stratified limestones of the El Abra Formation, which is the main host to the fluorite mineralization. The color of fluorite varies from violet to yellow-brown to red. Volcanic rocks may present weak argillization and hematitization along fractures, affecting both the volcanic and sedimentary rocks. Dissolution breccias filled by fluorite and calcite are common surrounding the main mineralized bodies, where fluorite stalactites are particularly conspicuous (Figure 5).

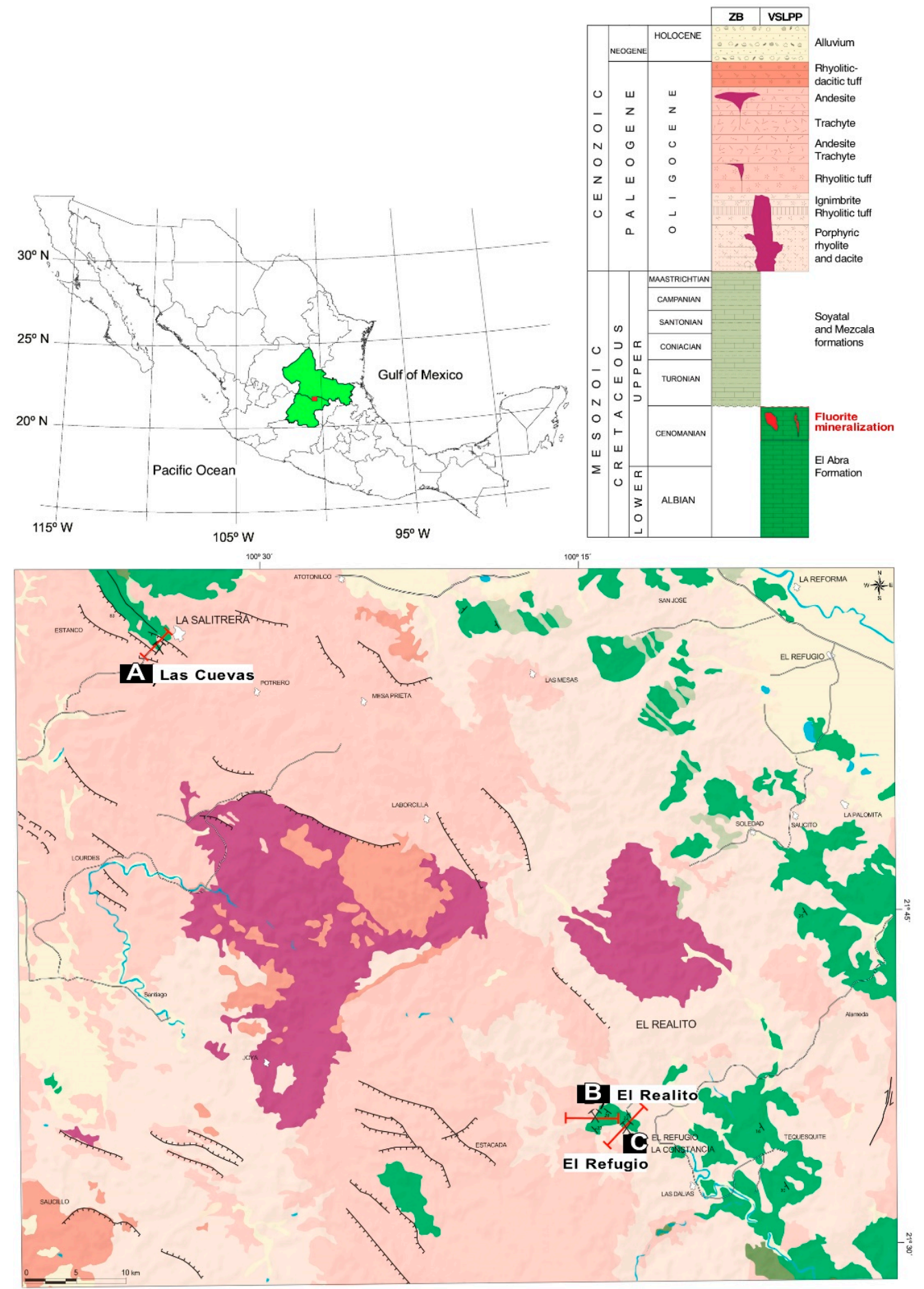

Figure 2. Geology of the area that includes the Las Cuevas, El Refugio, La Constancia, and El Realito fluorite deposits. Modified from Reference [30]. 


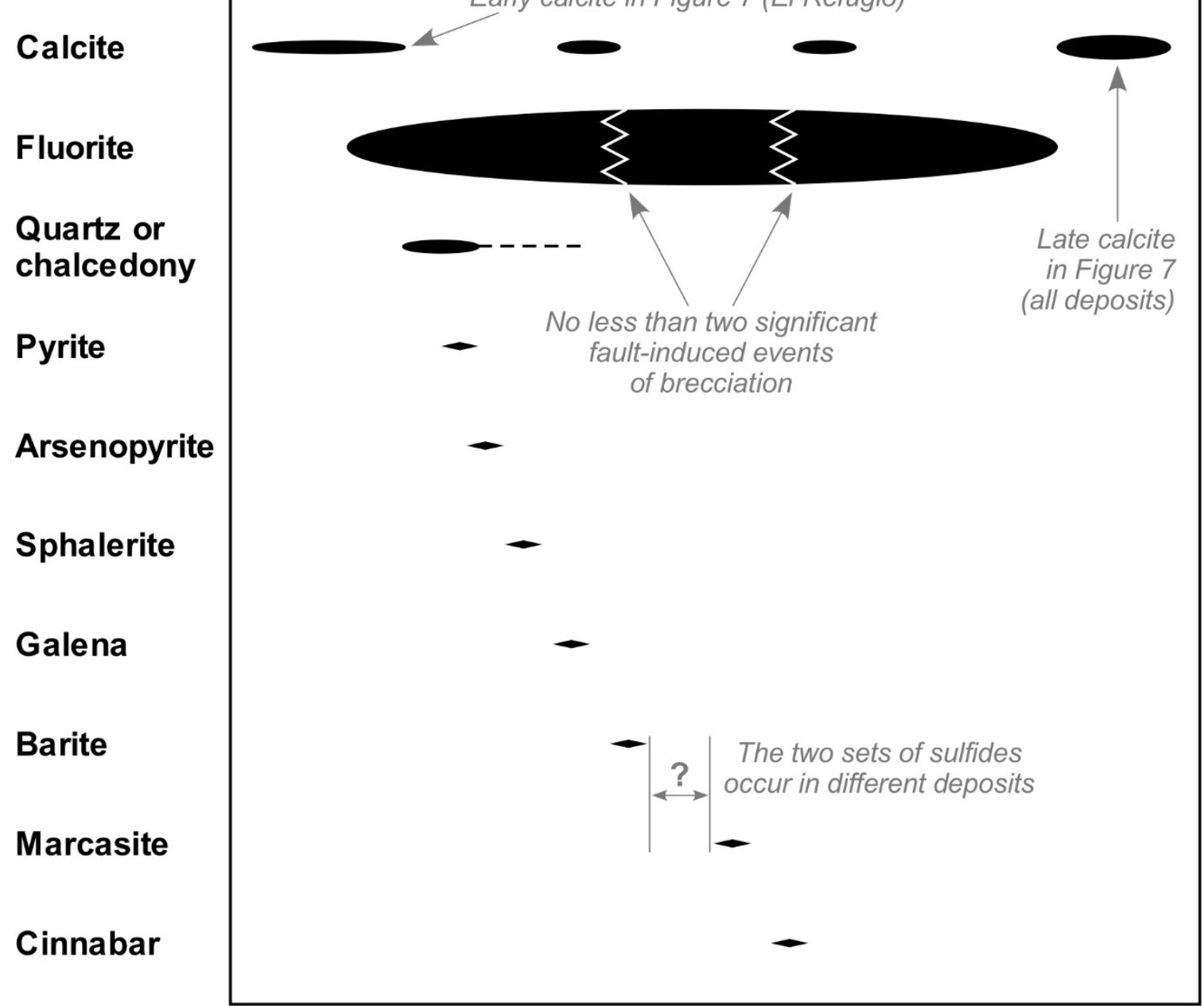

Figure 3. Generalized paragenetic sequence of the fluorite deposits at the Las Cuevas-Río Verde cluster, with reference to paragenetic sections that were sampled for fluid inclusion studies.

\subsection{The Rio Verde Mineralized Area}

Mining at the El Realito deposit (Guanajuato), the second-largest fluorite deposit in size and grade of the Las Cuevas-Río Verde region, has been operating since 1954, with an average grade of $75 \%$ fluorite. The mineralization consists of complex ore bodies (20 to $150 \mathrm{~m}$ in diameter and up to $300 \mathrm{~m}$ deep) that extend for about $500 \mathrm{~m}$ along regional NW-SE structures. The irregular to vertical chimney-like morphologies of these bodies are the product of the filling of karstic cavities along the reactivated fault contact between carbonate and intrusive rocks [31,32]. Carbonate rocks affected by dissolution in the vicinity of karstic cavities act as additional favorable porosity for the emplacement of fluorite bodies, along with intraclastic porosity, which represents $30 \%$ of mineralization [31]. In general, in the sequence of mineralization, the precipitation of fluorite is predated by calcite (Figure 3), which is the main gangue mineral. Fluorite is present in a variety of textures (geode and breccia lining; and botryoidal, columnar, and saccharoidal aggregates), much like those in the Las Cuevas deposit. Chalcedony, marcasite, and cinnabar occur as subordinate minerals. 
A Las Cuevas

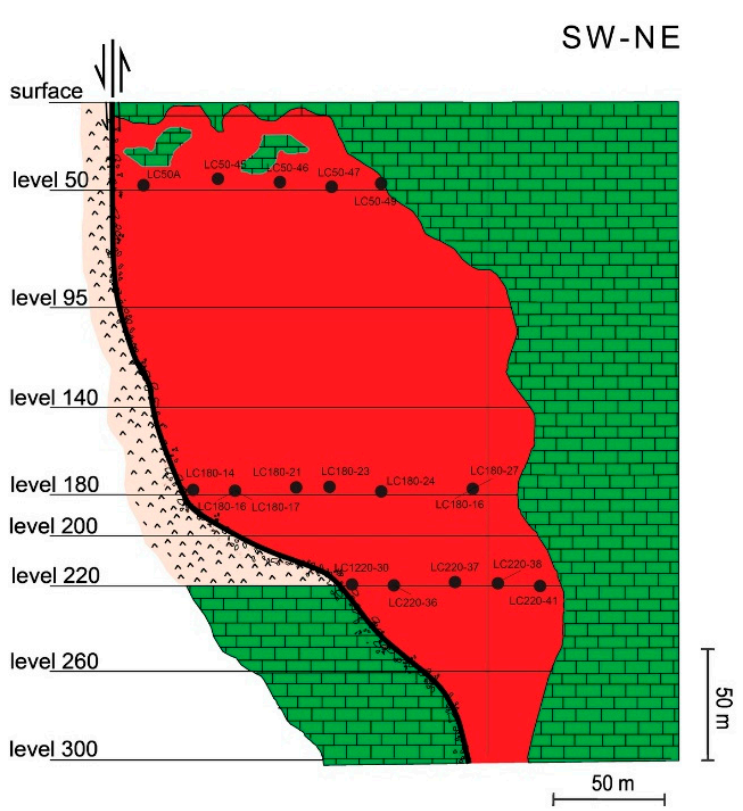

B El Realito

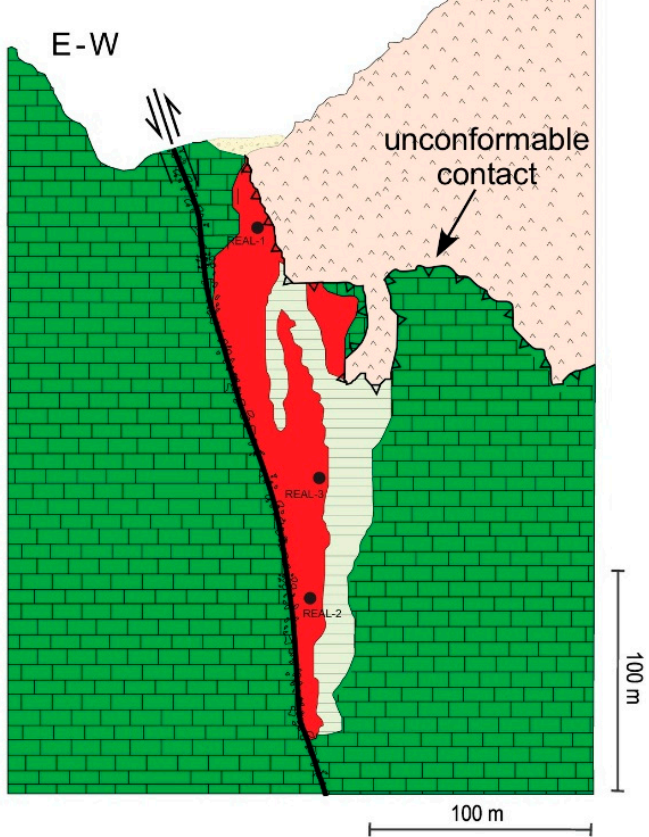

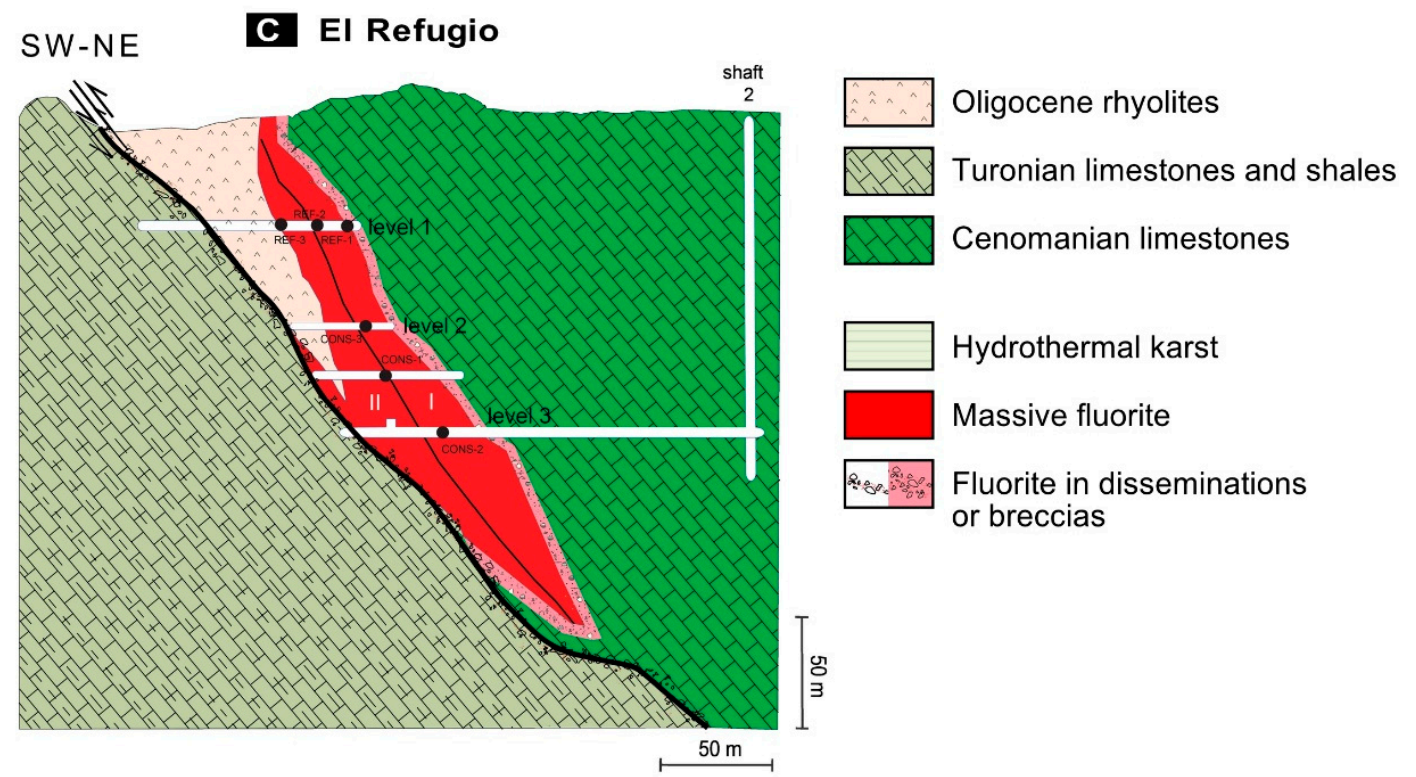

Figure 4. Schematic cross-sections from the Las Cuevas, El Refugio, and El Realito mines showing mineralized orebodies and their relation to host rocks. Modified from References [29,31]. Black dots indicate the location of samples used in this study. 

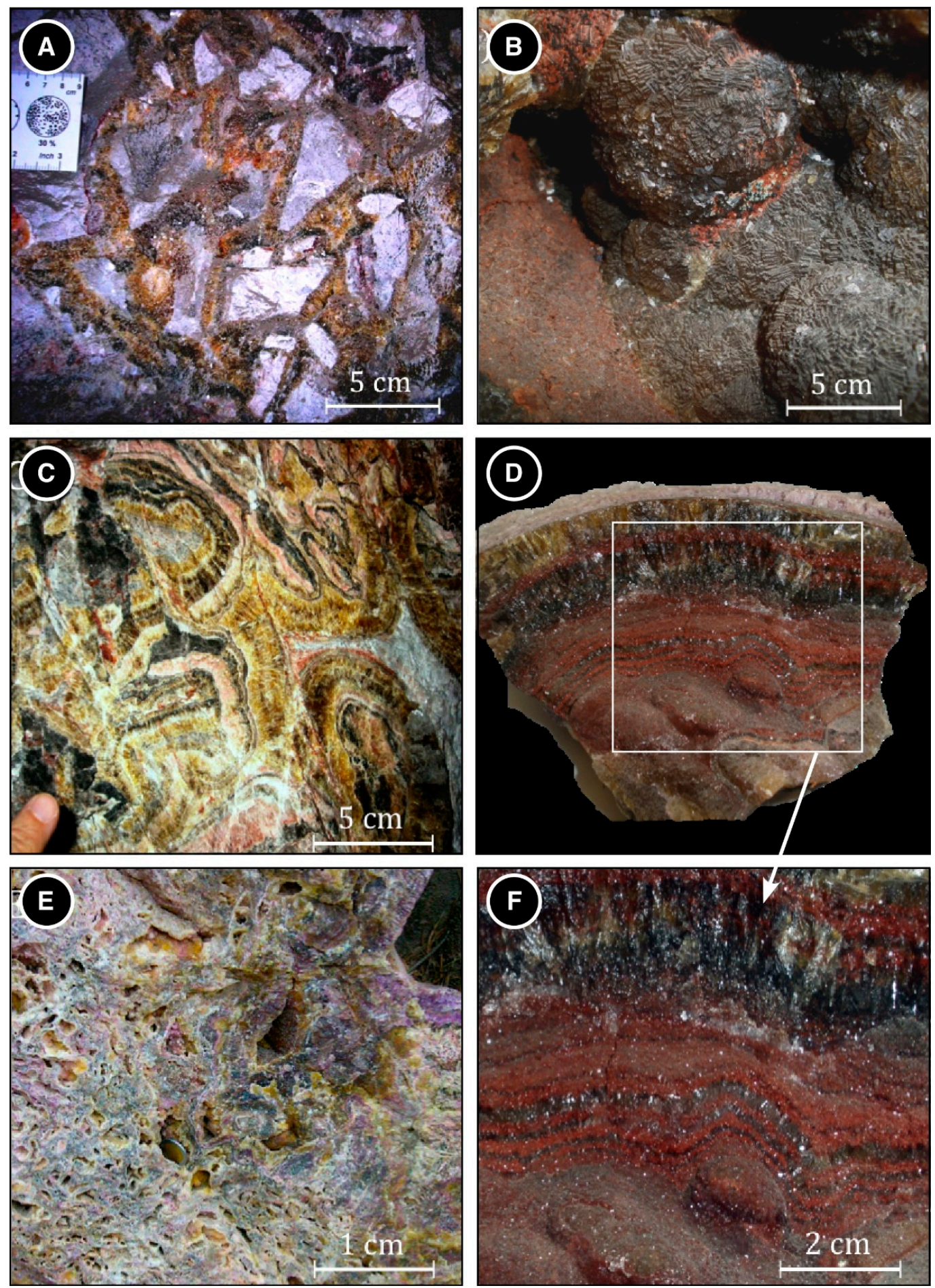

Figure 5. Representative textures of fluorite mineralization in the Las Cuevas deposit. (A) Breccia with carbonate rock fragments cemented by brown fluorite. (B) Botryoidal aggregates of brown fluorite in decimeter-size cavities. (C) Self-brecciation of banded multicolored fluorite cemented by honey to greenish-colored fluorite and late calcite (in white). (D,F) Details of stalactitic structures in fluorite that formed in hydrothermal karst. (E) Sponge-like aggregates of multicolored saccharoidal fluorite. (F) Saccharoidal textures and microbands of brown and red fluorite.

The El Refugio and La Constancia deposits (San Luis Potosí) represent the smallest resource in fluorite of the three areas in the Las Cuevas-Río Verde region. They are located at the contact between massive limestone (El Abra Formation) and shales and limestones of the Soyatal Formation (Figure 4). 
The mineralized body also has a NW-SE strike and dips $60^{\circ}$ to the NE. It has an oval shape (50 m wide and $200 \mathrm{~m}$ long, on average), changing to tabular at a 250-m depth, where it narrows down rapidly and ceases to be. Fluorite is massive, with an average grade of $83 \%$. The mineralized body is surrounded by a kaolinization halo, visible in the neighboring intrusive rocks, and fills a karstic cavity [31].

\section{Methodology}

Fluid inclusion studies were carried out in representative fluorite, calcite, and quartz samples of the Las Cuevas, El Refugio, El Realito, and La Constancia deposits, for nearly 1400 individual inclusions. The studied samples were obtained from different sections in the paragenetic sequence (Figure 3), so as to allow for the determination of the evolution with time of mineralizing fluids, hence the reference to early or late calcite. The studied samples were doubly polished sections (100 to $150 \mu \mathrm{m}$ thick). Primary, pseudosecondary, and secondary inclusions were found. The analyzed inclusions were liquid-rich (degree of filling, F > 0.95; Figure 6), contained no daughter crystals or unmixed liquids, and their sizes ranged typically between 20 and $100 \mu \mathrm{m}$. Primary fluid inclusions occurred in growth zones parallel to crystal faces or occurred as solitary inclusions or isolated groups of inclusions lacking healed fractures (in cases in which growth zones could not be identified). Pseudosecondary inclusions occurred along fractures that were covered by later growth zones. Several primary and pseudosecondary inclusions showed evidence (or were suspects) of necking after liquid contraction, stretching, or leakage. Necking was manifested in groups of fluid inclusions, resulting in a wide range of vapor-to-liquid ratios (degree of filling). These had relatively irregular shapes, distinct from stair-like shapes that are typical of fluorite, with elongated terminations that pointed to similar terminations in other inclusions. For this paper, only primary inclusions were analyzed. All fluid inclusions homogenized into a liquid phase. Microthermometric studies were carried out on a Linkam THMSG600 heating-freezing stage. Calibration runs showed that the measurements were accurate to $\pm 0.2{ }^{\circ} \mathrm{C}$ for low-temperature measurements, and to $\pm 2{ }^{\circ} \mathrm{C}$ for high-temperature measurements. Salinities were calculated by using freezing point depression temperatures [33]. The obtained microthermometric data are displayed in Table 1 and Figure 7.

Table 1. Summary of data obtained through microthermometry of fluid inclusions from the Las Cuevas cluster of fluorite deposits, states of San Luis Potosí and Guanajuato, Central Mexico.

\begin{tabular}{|c|c|c|c|c|c|c|}
\hline & & & & $\operatorname{Th}\left({ }^{\circ} \mathrm{C}\right)$ & $\operatorname{Tmi}\left({ }^{\circ} \mathrm{C}\right)$ & Salinity (wt \% $\mathrm{NaCl}$ Equiv) \\
\hline Deposit & Sample & Mineral & $n$ & $\mathrm{~m} / \mathbf{a} / \mathbf{M}$ & $\mathbf{M} / \mathbf{a} / \mathbf{m}$ & $\mathrm{m} / \mathbf{a} / \mathbf{M}$ \\
\hline \multirow[t]{15}{*}{ Las Cuevas } & LC-220-30 & fluorite & 29 & $60 / 69 / 73$ & 0 & 0 \\
\hline & & calcite & 40 & $55 / 62 / 70$ & -0.1 & 0.2 \\
\hline & LC-220-36 & fluorite & 22 & $94 / 110 / 125$ & -0.1 & 0.2 \\
\hline & LC-220-37 & fluorite & 17 & $75 / 77 / 79$ & -0.1 & 0.2 \\
\hline & & fluorite & 16 & $77 / 82 / 85$ & -0.1 & 0.2 \\
\hline & LC-220-38 & fluorite & 33 & $73 / 78 / 85$ & -0.1 & 0.2 \\
\hline & & calcite & 24 & $55 / 59 / 61$ & -0.1 & 0.2 \\
\hline & LC-220-40 & fluorite & 38 & $67 / 75 / 80$ & -0.1 & 0.2 \\
\hline & & fluorite & 19 & $75 / 83 / 99$ & -0.1 & 0.2 \\
\hline & LC-220-41 & fluorite & 20 & $93 / 106 / 124$ & -0.1 & 0.2 \\
\hline & LC-220-42 & fluorite & 18 & $75 / 86 / 95$ & -0.1 & 0.2 \\
\hline & LC-220-43 & fluorite & 13 & $65 / 81 / 98$ & -0.1 & 0.2 \\
\hline & & calcite & 20 & $61 / 65 / 70$ & -0.1 & 0.2 \\
\hline & LC-220-43B & fluorite & 12 & $72 / 86 / 108$ & -0.1 & 0.2 \\
\hline & & calcite & 20 & $65 / 68 / 70$ & -0.1 & 0.2 \\
\hline
\end{tabular}


Table 1. Cont.

\begin{tabular}{|c|c|c|c|c|c|c|}
\hline & & & & $\operatorname{Th}\left({ }^{\circ} \mathrm{C}\right)$ & $\operatorname{Tmi}\left({ }^{\circ} \mathrm{C}\right)$ & Salinity (wt \% $\mathrm{NaCl}$ Equiv) \\
\hline \multirow[t]{36}{*}{ Deposit } & Sample & Mineral & $n$ & $\mathrm{~m} / \mathrm{a} / \mathrm{M}$ & $\mathbf{M} / \mathbf{a} / \mathbf{m}$ & $\mathrm{m} / \mathbf{a} / \mathbf{M}$ \\
\hline & LC-180-1 & fluorite & 45 & $66 / 72 / 79$ & -0.1 & 0.2 \\
\hline & & calcite & 26 & $49 / 61 / 65$ & -0.1 & 0.2 \\
\hline & LC-180-2 & fluorite & 25 & $70 / 75 / 84$ & -0.1 & 0.2 \\
\hline & LC-180-6 & fluorite & 12 & $103 / 105 / 111$ & -0.1 & 0.2 \\
\hline & & calcite & 10 & $72 / 76 / 88$ & -0.1 & 0.2 \\
\hline & LC-180-7D & fluorite & 11 & $104 / 106 / 113$ & -0.1 & 0.2 \\
\hline & LC-180-9 & calcite & 24 & $49 / 61 / 66$ & -0.1 & 0.2 \\
\hline & LC-180-11 & fluorite & 25 & $70 / 73 / 77$ & -0.1 & 0.2 \\
\hline & LC-180-12 & quartz & 8 & $101 / 109 / 120$ & -0.1 & 0.2 \\
\hline & & fluorite & 26 & $69 / 71 / 76$ & -0.1 & 0.2 \\
\hline & LC-180-13 & fluorite & 16 & $72 / 83 / 105$ & -0.1 & 0.2 \\
\hline & LC-180-14 & fluorite & 17 & $89 / 99 / 109$ & -0.2 & 0.4 \\
\hline & LC-180-14B & fluorite & 21 & $72 / 84 / 100$ & -0.1 & 0.2 \\
\hline & LC-180-15 & fluorite & 32 & $76 / 89 / 115$ & -0.1 & 0.2 \\
\hline & LC-180-16 & fluorite & 17 & $70 / 76 / 97$ & -0.1 & 0.2 \\
\hline & LC-180-17 & fluorite & 16 & $55 / 63 / 75$ & -0.1 & 0.2 \\
\hline & LC-180-18 & fluorite & 9 & $78 / 83 / 92$ & -0.1 & 0.2 \\
\hline & LC-180-19 & fluorite & 16 & $60 / 63 / 70$ & -0.1 & 0.2 \\
\hline & LC-180-20 & fluorite & 6 & $78 / 88 / 100$ & -0.1 & 0.2 \\
\hline & LC-180-21 & fluorite & 23 & $60 / 62 / 70$ & -0.1 & 0.2 \\
\hline & LC-180-22 & fluorite & 30 & $65 / 76 / 84$ & -0.1 & 0.2 \\
\hline & LC-180-23 & fluorite & 14 & $85 / 90 / 95$ & -0.1 & 0.2 \\
\hline & & fluorite & 26 & $71 / 75 / 82$ & -0.1 & 0.2 \\
\hline & LC-180-24 & fluorite & 14 & $79 / 82 / 85$ & -0.1 & 0.2 \\
\hline & LC-180-25 & fluorite & 52 & $75 / 84 / 105$ & -0.1 & 0.2 \\
\hline & LC-180-26 & fluorite & 16 & $76 / 87 / 90$ & -0.1 & 0.2 \\
\hline & LC-180-27 & fluorite & 40 & $75 / 87 / 92$ & -0.1 & 0.2 \\
\hline & LC-180-29A & fluorite & 31 & $61 / 66 / 69$ & -0.1 & 0.2 \\
\hline & LC-180-46 & fluorite & 20 & $68 / 72 / 78$ & -0.1 & 0.2 \\
\hline & LC-SUP-50A & quartz & 11 & $148 / 163 / 177$ & -0.1 & 0.2 \\
\hline & LC-SUP-45 & fluorite & 11 & $80 / 84 / 95$ & -0.1 & 0.2 \\
\hline & LC-SUP-49 & calcite & 19 & $64 / 66 / 68$ & -0.1 & 0.2 \\
\hline & LC-SUP-47 & fluorite & 21 & $64 / 67 / 78$ & -0.1 & 0.2 \\
\hline & LC-SUP-46A & fluorite & 38 & $80 / 89 / 100$ & -0.1 & 0.2 \\
\hline & LC-SUP-46B & fluorite & 34 & $90 / 96 / 102$ & -0.1 & 0.2 \\
\hline Las Cuevas & & quartz & & 101 to 177 & -0.1 & 0.2 \\
\hline \multirow[t]{3}{*}{ (All samples) } & & fluorite & & 55 to 125 & 0 to -0.2 & 0 to 0.4 \\
\hline & & calcite & & 49 to 88 & -0.1 & 0.2 \\
\hline & & all minerals & & 49 to 177 & -0.1 to -0.2 & 0.2 to 0.4 \\
\hline \multirow[t]{3}{*}{ El Refugio } & REF-1 & fluorite & 16 & $77 / 79 / 79$ & $-0.9 /-0.9 /-1$ & $1.6 / 1.6 / 1.7$ \\
\hline & $R E F-2$ & calcite & 30 & $125 / 127 / 130$ & -0.1 & 0.2 \\
\hline & REF-3 & fluorite & 50 & $89 / 98 / 114$ & $-0.8 /-0.9 /-1.1$ & $1.4 / 1.6 / 1.9$ \\
\hline \multirow[t]{2}{*}{ La Constancia } & CONST-1 & quartz & 10 & $98 / 100 / 102$ & $-0.9 /-0.9 /-1$ & 1.6/1.6/1.7 \\
\hline & & fluorite & 24 & $80 / 85 / 98$ & -0.3 & 0.5 \\
\hline
\end{tabular}


Table 1. Cont.

\begin{tabular}{ccccccc}
\hline & & & & $T h\left({ }^{\circ} \mathbf{C}\right)$ & $T m i\left({ }^{\circ} \mathbf{C}\right)$ & Salinity (wt \% NaCl Equiv) \\
\hline Deposit & Sample & Mineral & $n$ & $\mathbf{m} / \mathbf{a} / \mathbf{M}$ & $\mathbf{M} / \mathbf{a} / \mathbf{m}$ & $\mathbf{m} / \mathbf{a} / \mathbf{M}$ \\
\hline & CONST-2 & fluorite & 44 & $85 / 100 / 118$ & $-0.3 /-0.5 /-0.8$ & $0.5 / 0.9 / 1.4$ \\
\hline CONST-3 & calcite & 49 & $76 / 80 / 86$ & $-0.1 /-0.1 /-0.2$ & $0.2 / 0.2 / 0.4$ \\
\hline El Refugio- & & quartz & & 98 to 102 & -0.9 to -1 & 1.6 to 1.7 \\
\hline La Constancia & & fluorite & 77 to 118 & -0.8 to -1.1 & 1.4 to 1.9 \\
\hline group & & calcite & & 76 to 130 & -0.1 to -0.2 & 0.2 to 0.4 \\
\hline Ell samples) & & all minerals & & 76 to 130 & -0.1 to -1.1 & 0.2 to 1.9 \\
\hline & REAL-1 & calcite & 7 & $56 / 57 / 58$ & -0.1 & 0.2 \\
\hline & REAL-2 & calcite & 23 & $65 / 69 / 89$ & -0.2 & 0.4 \\
\hline & REAL-3 & calcite & 11 & $64 / 65 / 67$ & -0.2 & 0.4 \\
\hline
\end{tabular}

Key: $\mathrm{a}=$ average value, $\mathrm{M}=$ highest value, $\mathrm{m}=$ lowest value, $n=$ number of analyzed fluid inclusions, $T h=$ temperature of homogenization, $T m i=$ temperature of ice melting (freezing point depression). General data for each group of deposits are shaded in gray. The calcite sample from El Refugio in bold and italics (calcite) denotes early calcite in the paragenetic sequence (see Figure 3).

The isotopic composition of representative samples of calcite and recrystallized carbonate rocks that host the fluorite deposits was determined by means of the basic technique of Reference [34] and using the method described by References [35,36]. This was achieved by using a Finnigan MAT 253 Mass Spectrometer with a dual system of sample introduction and auxiliary Gas Bench with an autosampler GC Pal and aluminum heating plate with a thermostat coupled to the spectrometer, available at the Laboratorio Nacional de Geoquímica y Mineralogía (LANGEM). Using the Gas Bench at $25^{\circ} \mathrm{C}, 0.6 \mathrm{mg}$ of carbonate was weighed in exetainer tubes on a Mettler Toledo MX5 microbalance with a $0.001-\mathrm{mg}$ resolution and placed on the aluminum heating plate. Each tube was injected with 99.995\% pure helium for $10 \mathrm{~min}$ in order to eliminate air using a double-way needle. Later, tubes were injected with 10 drops of $100 \%$ orthophosphoric acid. This technique has the objective of converting the carbonate of the sample into $\mathrm{CO}_{2}$ through reaction with the acid. Then the isotopic composition of $\mathrm{CO}_{2}$ was determined. The results are displayed in Table 2 and Figure 8 as per mil deviations from the VPDB standard using delta notation $\left(\delta^{18} \mathrm{O}\right.$ and $\left.\delta^{13} \mathrm{C}\right)$.

Table 2. Carbon and oxygen isotopic data from host Cretaceous carbonate rocks of the Las Cuevas fluorite deposit and late hydrothermal calcite.

\begin{tabular}{|c|c|c|c|c|}
\hline Sample & Material & $\delta^{13} C_{\text {VPDB }}$ & $\delta^{18} \mathrm{O}_{\text {VPDB }}$ & $\delta^{18} \mathrm{O}_{\text {VSMOW }}$ \\
\hline LC-SUP-49 & Calcite & -3.19 & -14.81 & 15.64 \\
\hline LC-180-3 & Calcite & -5.67 & -14.01 & 16.47 \\
\hline LC-180-7 & Calcite & -4.26 & -14.45 & 16.01 \\
\hline LC-180-8 & Calcite & -5.54 & -12.76 & 17.76 \\
\hline LC-180-9 & Calcite & -3.82 & -14.28 & 16.19 \\
\hline LC-180-15 & Calcite & -2.27 & -15.42 & 15.01 \\
\hline LC-180-17 & Calcite & -3.09 & -12.99 & 17.52 \\
\hline LC-180-23 & Calcite & -5.41 & -15.60 & 14.82 \\
\hline LC-180-25 & Calcite & -4.93 & -13.89 & 16.59 \\
\hline LC-180-26 & Calcite & -3.58 & -14.60 & 15.86 \\
\hline LC-180-28 & Calcite & -3.83 & -14.48 & 15.98 \\
\hline LC-220-34 & Calcite & -3.77 & -14.17 & 16.30 \\
\hline LC-220-37 & Calcite & -4.29 & -13.98 & 16.50 \\
\hline LC-220-38 & Calcite & -2.27 & -16.74 & 13.65 \\
\hline
\end{tabular}


Table 2. Cont

\begin{tabular}{ccccc}
\hline Sample & Material & $\boldsymbol{\delta}^{\mathbf{1 3}} \mathbf{C}_{\text {VPDB }}$ & $\boldsymbol{\delta}^{\mathbf{1 8}} \mathbf{O}_{\text {VPDB }}$ & $\boldsymbol{\delta}^{\mathbf{1 8}} \mathbf{O}_{\text {VSMOW }}$ \\
\hline LC-220-43 & Calcite & -1.84 & -16.45 & 13.95 \\
\hline LC-SUP-45A & Limestone & 0.16 & -7.37 & 23.31 \\
\hline LC-SUP-45B & Limestone & -2.39 & -14.03 & 16.45 \\
\hline LC-SUP-48 & Limestone & -1.61 & -9.57 & 21.04 \\
\hline LC-180-18 & Limestone & 1.10 & -7.67 & 23.01 \\
\hline LC-220-30 & Limestone & -2.16 & -13.93 & 16.55 \\
\hline LC-220-35 & Limestone & 0.20 & -10.10 & 20.49 \\
\hline LC-220-43 & Limestone & -0.12 & -10.93 & 19.64 \\
\hline
\end{tabular}
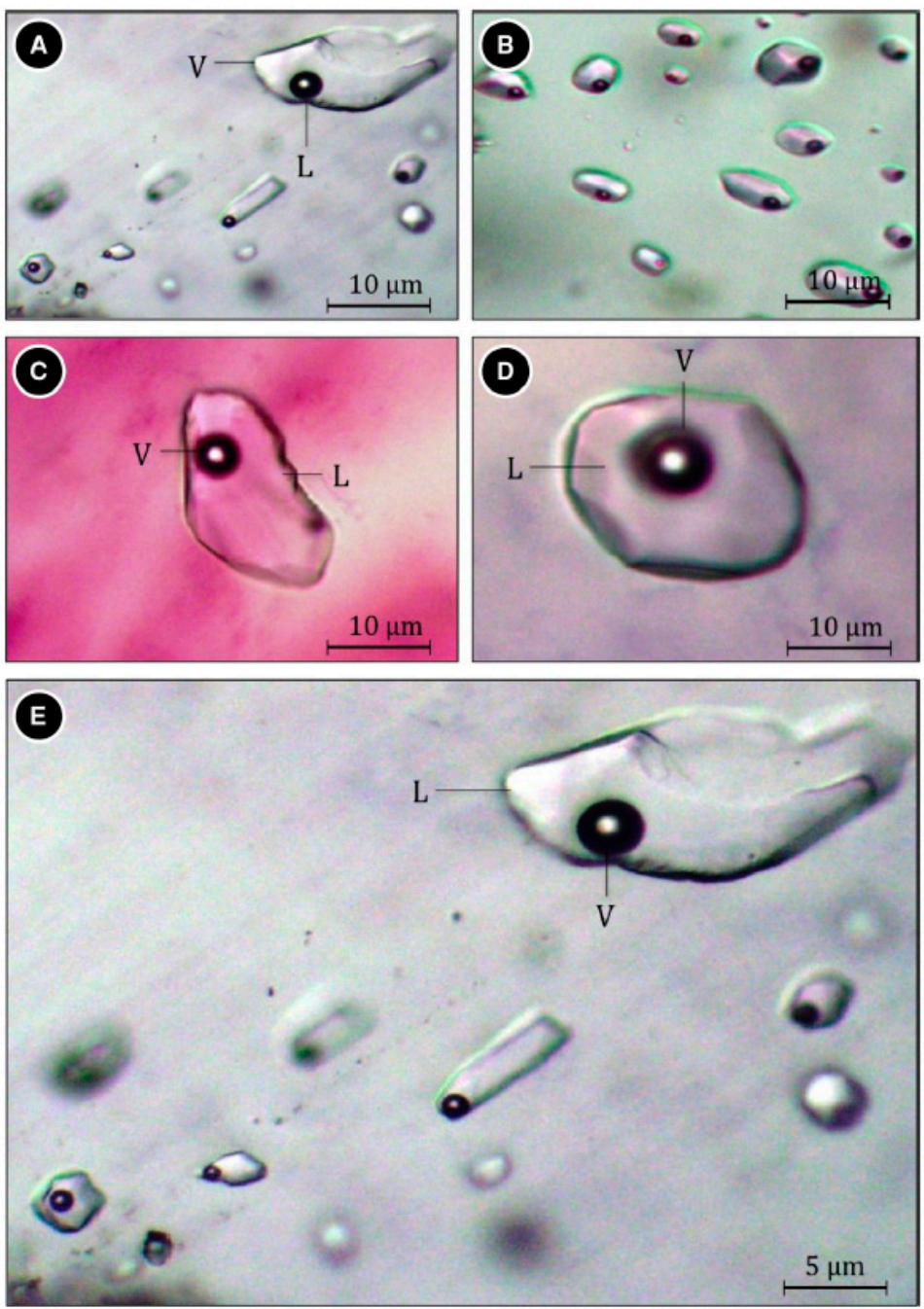

Figure 6. Representative primary fluid inclusions in fluorite from the studied deposits in the Las Cuevas-Río Verde cluster: (A,B) Las Cuevas, (C) El Realito, (D) El Refugio, (E) La Constancia. Key: $\mathrm{L}=$ liquid, $\mathrm{V}=$ vapor. 


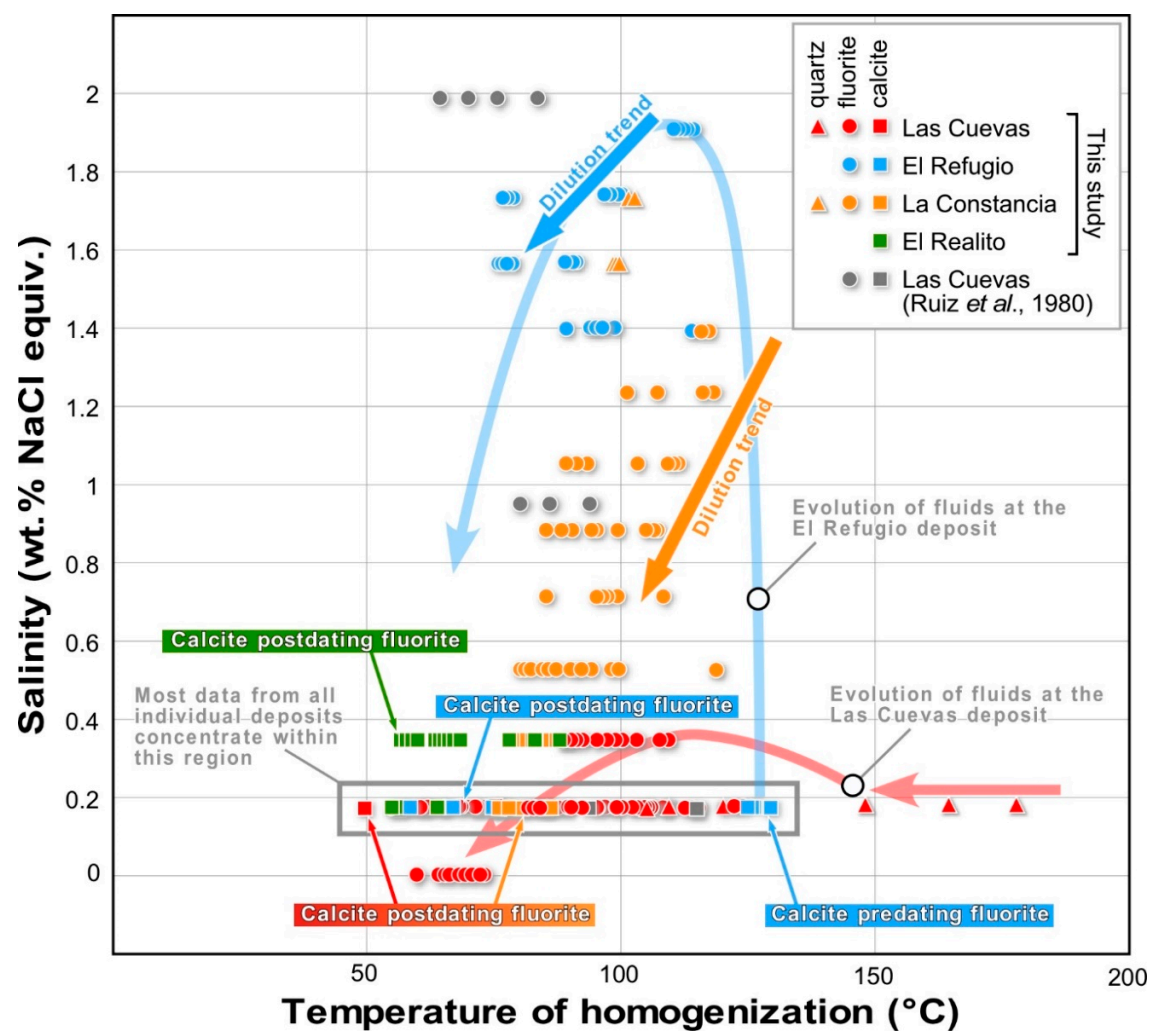

Figure 7. Correlation between temperatures of homogenization from fluid inclusions and the calculated salinities upon freezing point depression in the studied fluorite deposits of the Las Cuevas-Río Verde cluster. See data in Table 1. The dilution trends marked in this figure correspond only to groups of fluid inclusion associations (FIA) that presented such a trend in a timeline in the same sample, as defined by the decrease of both temperatures of homogenization and salinities with time, and the timeline was determined based on petrographic criteria (essentially, early to late growth zones within the same crystal). The area in the graph in which most data concentrate means that 1100 out of 1367 studied inclusions had a salinity of $0.2 \mathrm{wt} \% \mathrm{NaCl}$ equiv.

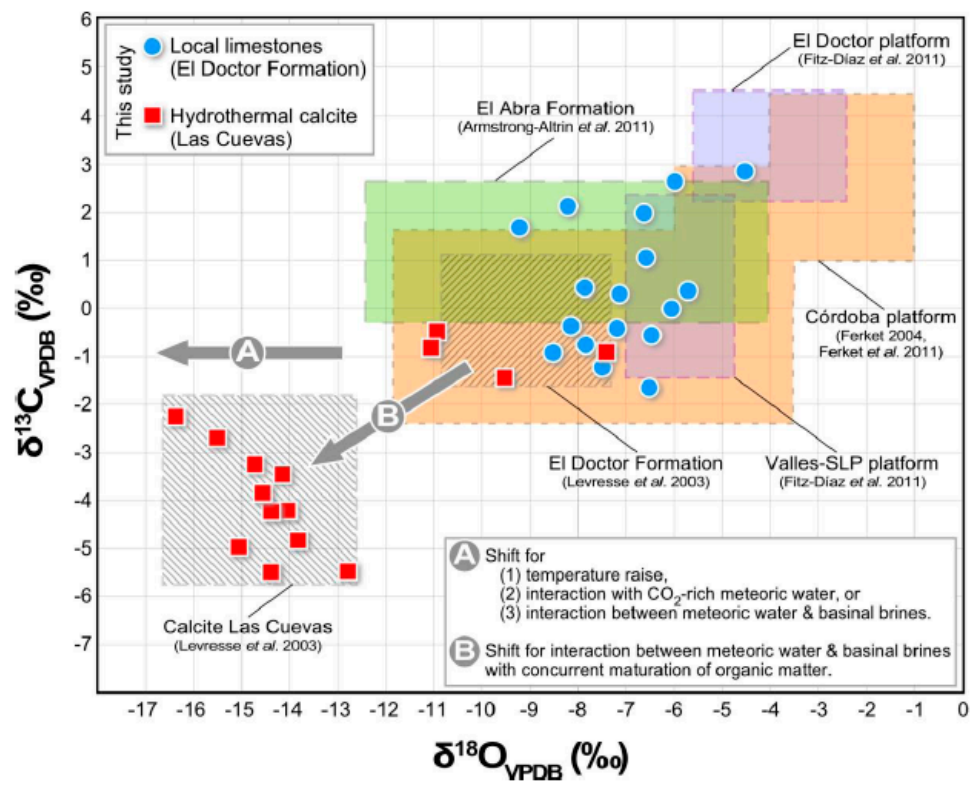

Figure 8. Correlation between $\delta^{18} \mathrm{O}$ and $\delta^{13} \mathrm{C}$ values (VPDB) for host rock samples (blue circles) and gangue hydrothermal calcite (red squares) in the Las Cuevas fluorite deposit, compared to the data available in the literature for regional platform carbonate rocks and calcite. See data in Table 2. 


\section{Results}

The results of microthermometry of fluid inclusions in this paper (Table 1 and Figure 7) did not differ significantly from preexisting studies for the Las Cuevas deposit [4,6], as mineralizing fluids were very dilute and low-temperature in all cases.

At the Las Cuevas deposit ("G" body"), ice-melting temperatures (Tmi) occurred between and 0 and $-0.2{ }^{\circ} \mathrm{C}$, which corresponded to salinities between 0 and $0.4 \mathrm{wt} \% \mathrm{NaCl}$ equiv, and temperatures of homogenization $(T h)$ ranged between 49 and $177^{\circ} \mathrm{C}$. The range of variation of salinities was very narrow, and most of them were $0.2 \mathrm{wt} \% \mathrm{NaCl}$ equiv regardless of the host mineral. No significant variations in $T h$ or salinity were observed between different generations of fluorite, but $T h$ was higher in quartz than in other minerals (between 101 and $177^{\circ} \mathrm{C}$ ), and was lower in calcite (between 49 and $88^{\circ} \mathrm{C}$ ) (which occurs late in the paragenetic sequence), whereas Th in fluorite ranged between 55 and $125^{\circ} \mathrm{C}$.

At the deposits of the Río Verde mineralized area, Tmi ranged between -0.1 and $-1.1^{\circ} \mathrm{C}$, which corresponded to salinities between 0.2 and $1.9 \mathrm{wt} \% \mathrm{NaCl}$ equiv, and $\mathrm{Th}$ ranged between $56^{\circ}$ and $130{ }^{\circ} \mathrm{C}$. The highest salinity fluids were found in fluorite at El Refugio (1.4 to $1.9 \mathrm{wt} \% \mathrm{NaCl}$ equiv). The broadest variation in salinity was recorded at the El Refugio deposit (between 0.2 and $1.9 \mathrm{wt} \%$ $\mathrm{NaCl}$ equiv), and the narrowest at $\mathrm{El}$ Realito (between 0.2 and $0.4 \mathrm{wt} \% \mathrm{NaCl}$ equiv, similar to those at the Las Cuevas deposit). Calcite samples showed both the highest and lowest $T h$ in these deposits (between 125 and $130{ }^{\circ} \mathrm{C}$ for early calcite at El Refugio, and between 56 and $89{ }^{\circ} \mathrm{C}$ for late calcite at El Realito); and Th ranged between 77 and $118^{\circ} \mathrm{C}$ in fluorite, and between 98 and $102^{\circ} \mathrm{C}$ in quartz, which is an early mineral in the paragenetic sequence (Figure 3 ).

No melting at eutectic conditions or melting of hydrohalite could be observed during freezing-heating runs of fluid inclusions. Therefore, no further remarks can be drawn aside from $\mathrm{NaCl}$-dominated fluids with overall very low salinities.

The obtained $\delta^{18} \mathrm{O}$ and $\delta^{13} \mathrm{C}$ data (Table 2 and Figure 8) ranged as follows: $\delta^{18} \mathrm{O}$ between -14.03 and $-7.37 \%$ VPDB, and $\delta^{13} \mathrm{C}$ between -2.39 and $0.20 \%$ VPDB, in recrystallized host limestones of the El Doctor Formation; and $\delta^{18} \mathrm{O}$ between -15.60 and $-12.99 \%$ VPDB, and $\delta^{13} \mathrm{C}$ between -5.56 and $-1.84 \%$ VPDB, in hydrothermal calcite (late in the paragenetic sequence) associated with fluorite mineralization at the Las Cuevas deposit.

In comparison, limestones at the El Doctor (EDP) and Valles-San Luis Potosí (VSLPP) platforms (El Doctor Formation, which correlates with the El Abra Formation) have $\delta^{18} \mathrm{O}$ values that range between -5.60 and $-2.44 \%$ VPDB (EDP) and between -7.00 and $-4.86 \%$ VPDB (VSLPP), and have $\delta^{13} \mathrm{C}$ values between 2.17 and 4.47\% VPDB (EDP) and between -1.31 and 2.21\%o VPDB (VSLPP) [16]. In other studies, it was determined that the limestones of the El Abra Formation have $\delta^{18} \mathrm{O}$ values that range between -12.41 and $-4.02 \%$ VPDB and $\delta^{13} \mathrm{C}$ values between -0.27 and $2.67 \%$ o VPDB $[37,38]$. Other Albian-Cenomanian carbonate rocks within a similar depositional environment nearby (the Córdoba platform) show $\delta^{18} \mathrm{O}$ values between -4 and $-1 \%$ VPDB, and $\delta^{13} \mathrm{C}$ values between 1 and 4.5\% VPDB for fresh rocks; $\delta^{18} \mathrm{O}$ values between -6 and $-3.5 \%$ VPDB, and $\delta^{13} \mathrm{C}$ values between 0.2 and $3 \%$ VPDB for authigenic dolomite; $\delta^{18} \mathrm{O}$ values between -16.7 and $-5 \%$ VPDB, and $\delta^{13} \mathrm{C}$ values between -18 and $-2.5 \%$ VPDB for authigenic calcite; and $\delta^{18} \mathrm{O}$ values between -11.9 and $-3.5 \%$ VPDB, and $\delta^{13} \mathrm{C}$ values between -2.4 and $1.9 \%$ VPDB, for vein calcite associated with late diagenesis $[39,40]$.

\section{Discussion}

\subsection{Sources for Mineralizing Fluids, Their Evolution, and Likely Mechanisms of Fluorite Precipitation}

Mineralizing fluids in the Las Cuevas-Río Verde cluster of stratabound fluorite deposits had very low salinities (overwhelmingly $0.2 \mathrm{wt} \% \mathrm{NaCl}$ equiv, and up to $1.9 \mathrm{wt} \% \mathrm{NaCl}$ equiv) and temperatures (mostly below $100{ }^{\circ} \mathrm{C}$, and up to $177^{\circ} \mathrm{C}$ ). The temperatures of mineral deposition were similar to those in similar stratabound fluorite deposits (described as part of the MVT clan) that occur across the 
rimming basins of the paleo-Gulf of Mexico, but the salinities in the studied deposits were strikingly much lower than in those of References [7-11]. Despite the narrowness in the variation of temperature and salinity of mineralizing fluids in the Las Cuevas-Río Verde cluster of fluorite deposits, the data in some samples from the El Refugio and La Constancia deposits showed dilution trends coupled with decreases in temperature (Figure 6). Such dilution was compatible with the interaction between low-temperature hydrothermal fluids and meteoric water. It cannot be ruled out that pre-dilution hydrothermal fluids could have been partly derived from meteoric water as well, provided that mineralizing fluids had such low salinities. In the El Refugio deposit, early fluids in calcite were hotter and more dilute than those in association with the formation of fluorite bodies, thus suggesting that the formation of fluorite required the entrainment of deep or deeply evolved fluids.

The obtained $\delta^{13} \mathrm{C}$ and $\delta^{18} \mathrm{O}$ data from the local host limestones (El Doctor and El Abra formations) plotted within the compositions of similar rocks, both at local and regional scales [4,16,38-40], and so did a few samples of hydrothermal calcite. That is, the isotopic composition of hydrothermal fluids was initially buffered by the composition of host rocks and then departed from such composition due to other processes, as the rest of the $\delta^{13} \mathrm{C}$ and $\delta^{18} \mathrm{O}$ data from hydrothermal calcite samples showed a shift toward lower values in both variables. These, in general, suggest (A) interaction between meteoric water and basinal brines, possibly with the concurrent maturation of organic matter; (B) interaction between $\mathrm{CO}_{2}$-rich meteoric water and basinal brines, and/or (C) a temperature rise that affected host rocks. The isotopic evolution of mineralizing fluids in the Las Cuevas-Río Verde cluster was similar to that in other basins that rimmed the paleo-Gulf of Mexico, namely those with MVT and associated deposits in northeastern Mexico and oil fields in southeastern Mexico [10]. However, mineralizing fluids in the Las Cuevas-Río Verde cluster differed greatly from the latter in having much lower salinities.

In the studied deposits, the wealth of data was compatible with the following evolution (Figure 9):

(A) Mineralizing fluids were initially dominantly constituted by meteoric water with a relatively prolonged residence time within the local sedimentary basins (deeply evolved meteoric water). These fluids would have become isotopically and compositionally equilibrated with (and buffered by) the host limestones at high water-rock interaction ratios;

(B) $\mathrm{CO}_{2}$-rich fresh meteoric water interacted with the sedimentary brines, further diluting them. It is likely that fresh meteoric water carried fluorine in solution by means of its interaction with the local hypabyssal and volcanic rhyolites, which were F-rich [2,20-25]. Although no relevant concentrations of fluorine have been detected in rhyolites of the study area (see the data for Río Verde in Reference [20], but these refer to a sole sample that is not representative of the broad extent of Oligocene volcanism in the region (see Figure 2)), such contents can be over $0.3 \%$ in Oligocene topaz rhyolites in central Mexico [20,21].

According to the above evolution and sources for water and chemical components of fluorite, the most likely mechanism for fluorite precipitation would have been associated with the reaction between calcium in low-salinity basinal brines (equilibrated with host limestones) and fluorine in shallow meteoric water (scavenged from topaz rhyolites), as their mixing was allowed to occur. Similar processes have been described for fluorite in different types of deposits, including MVT [7,8,41-43]. The most striking difference between such deposits and those at the Las Cuevas-Río Verde cluster is the large difference in salinities of mineralizing fluids between them, being exceptionally low in the latter. 

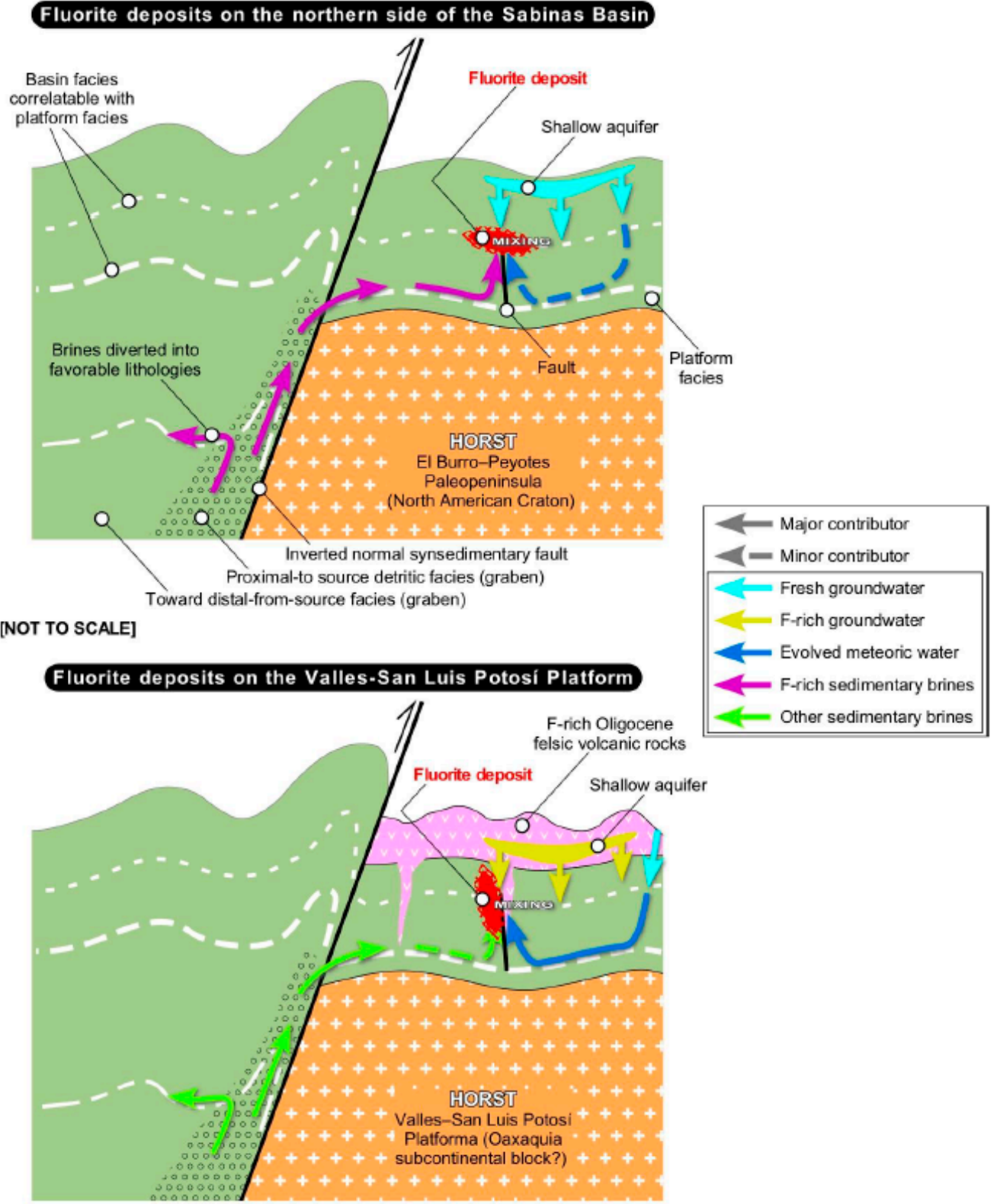

Figure 9. Conceptual model for the genesis of the fluorite deposits in the Las Cuevas-Río Verde cluster (down) in comparison to the model of the fluorite deposits on the northern side of the Sabinas Basin in Coahuila (adapted from Reference [11]).

Such a scenario would have been possible as upwelling deep fluids ascended through the faulted contact between Cretaceous limestones and Oligocene volcanic rocks (rhyolites, rhyodacites, and dacites) until they were made available for reaction with shallow groundwater that became enriched in rhyolite-derived fluorine (Figure 9). In this view, the faults that allowed the two types of fluids described above to be put in contact and facilitate their reaction constitute the crucial factor that favors the massive formation of fluorite bodies, hence the common occurrence of fluorite bodies by the shoulder of faults (Figure 4). Oligocene volcanic rocks are ubiquitous in the study area covering the Mesozoic sedimentary sequences (Figure 2), including those that are fluorine-rich (with associated tin deposits in the Río Verde region [44]). Therefore, fluorine from volcanic and hypabyssal rocks in the Álvarez Range (and, for this matter, in the rest of the San Luis Potosí volcanic field) can be easily made available by natural means to groundwater, as attested in present-day groundwater in the southern part of the San Luis Potosí state [45-47], creating a region with endemic fluorosis [48,49]. The precipitation 
of fluorite under low temperatures from low salinity fluids agrees with thermodynamic models in which the solubility of fluorite decreases steadily under $100{ }^{\circ} \mathrm{C}$ [50]. The possibility that fluorine was scavenged from F-rich local Oligocene acid volcanic and hypabyssal rocks is underpinned by the REE distribution pattern in the Las Cuevas fluorite [51], which is similar to that in fluorite deposits associated with felsic magmatism [52] and to that in the local Oligocene rocks [30,53].

\subsection{Type of Deposits}

Stratabound fluorite deposits in the Sabinas basin of northeastern Mexico, described as part of the MVT clan [7-11], are obvious subjects for comparison to the deposits at the Las Cuevas-Río Verde cluster. Fluorite deposits in both areas share several characteristics, namely (A) their preferential association with platform carbonates on basement highs, (B) their association with basinal brines and meteoric water as vehicles for mineralization, $(C)$ their association with faults and fractures as channelways that allowed different fluids to mix and react, (D) their nearly monomineralic character, and (E) the unnecessary direct participation of magmatic processes or fluids for their formation. These key characteristics draw the fluorite deposits at the Las Cuevas-Río Verde cluster near MVT-like models for their formation and rule out models of the magmatic-hydrothermal kind. However, a "full MVT" model cannot be invoked due to the particular characteristics of both upwelling fluids and groundwater, whose mixing originated these deposits. MVT-like fluorite deposits in northeastern Mexico are described to have formed after the mixing between (A) upwelling relatively hot and saline sedimentary brines that leached fluorine from basement rocks or clastic formations derived from their erosion, and (B) cool shallow groundwater chemically and isotopically equilibrated with host carbonate rocks [7-11]. In the Las Cuevas case, all the involved fluids are very dilute and their ultimate sources are essentially meteoric water, but also the characteristics of the two sources of fluids that mixed are "inverted" with respect to MVT-like deposits in northeastern Mexico. That is, the fluorine carriers are not hot and deep fluids, but cool and shallow, and the fluid equilibrated with limestones is not cool groundwater but relatively hot and deep fluids (meteoric water evolved by interaction with rocks of the Mesozoic sequence). The occurrence of hydrothermal karstification in all the mineralized bodies of the Las Cuevas-Río Verde cluster is also congruent with MVT-like deposits: The dissolution of carbonates would have provided plenty of the $\mathrm{Ca}^{2+}$ necessary to form the massive amount of fluorite in the Las Cuevas deposit.

Therefore, the fluorite deposits at the Las Cuevas-Río Verde cluster could stand as a particular case for MVT-like deposits in which the involvement of true sedimentary brines (that is, seawater evolved through a sedimentary basin) played nothing but an ancillary role in the constitution of mineralizing fluids. Such is possibly the case for the maturation of organic matter. Instead, the vehicles for mineralization were deep and shallow meteoric water. In the conceptual framework that described the formation of MVT and associated deposits in northeastern Mexico [9,11], the Las Cuevas deposits would have occupied the shallowest portion of a basin. In such locations, true basinal brines could be barely entrained, and only the special chemical composition of groundwater (explained above) would have guaranteed the formation of significant fluorite deposits. The MVT-like general model is emphasized by the occurrence of (A) MVT Pb-Zn and associated barite and celestine deposits, (B) red-bed-hosted copper deposits, and (C) sulfur deposits due to TSR processes in sulfate-rich evaporites along the northern margin of the Valles-San Luis Potosí platform (VSLPP) and on top of it (Figure 12 in Reference [2]). Their grouping along with fluorite deposits in the VSLPP was collectively branded as the San Luis-Valles province (San Luis Potosí, Nuevo León, and Tamaulipas). It can be regionally regarded as the southernmost termination of the continuum of deposits that belongs to the sedimentary-diagenetic realm of the provinces of northeastern Mexico (Coahuila and Nuevo León), the Chihuahua Trough province (Chihuahua and Texas), and the Río Grande Rift province and the Grants belt (New Mexico), and it is subject to a collective set of processes and evolution. 


\section{Conclusions}

The epigenetic, fault-controlled, fluorite deposits at the Las Cuevas-Río Verde cluster (states of San Luis Potosí and Guanajuato in Central Mexico) include Las Cuevas, which is the largest known fluorite deposit in the world. These deposits were formed by low temperature $\left(49\right.$ to $177^{\circ} \mathrm{C}$, but mostly below $100{ }^{\circ} \mathrm{C}$ ) and low salinity ( 0 to $1.9 \mathrm{wt} \% \mathrm{NaCl}$ equiv, but mostly $0.2 \mathrm{wt} \% \mathrm{NaCl}$ equiv) fluids, and are associated with hydrothermal karstification.

The obtained $\delta^{13} \mathrm{C}$ (between -2.39 and $0.20 \%$ VPDB) and $\delta^{18} \mathrm{O}$ (between -14.03 and $-7.37 \%$ VPDB) data from the local host limestones agreed with regionally representative values in the literature. The obtained $\delta^{13} \mathrm{C}$ (between -15.60 and $-12.99 \%$ VPDB) and $\delta^{18} \mathrm{O}$ (between -5.56 and $-1.84 \%$ VPDB) data from hydrothermal calcite associated with fluorite mineralization indicated that the isotopic composition of hydrothermal fluids initially reflected buffering by the host rocks, and then recorded the interaction between meteoric water and basinal brines, perhaps with concurrent maturation of organic matter.

The extremely low salinity of mineralizing fluids suggests that the water that underwent a certain degree of interaction with country rocks was ultimately fresh meteoric water. It would have interacted and mixed at depth with minor basinal brines before being entrained by faults toward the surface. It would have met shallow groundwater that had become enriched in fluorine by its interaction with topaz rhyolites and other F-rich volcanic rocks. Following the interaction (mixing and reaction) between diluted basinal brines and F-rich groundwater, the precipitation of fluorite ensued at temperatures mostly below $100{ }^{\circ} \mathrm{C}$.

Following this rationale, we likely ascribe the formation of the world-class fluorite deposits in the Las Cuevas-Río Verde cluster to a special category within the "clan" of Mississippi Valley Type deposits, instead of any type of magmatic-hydrothermal models. Unlike their relatives in northeastern Mexico (northern Sabinas basin), the F carrier in the studied deposits would have been groundwater (instead of basinal brines), and basinal brines (and thus the maturation of organic matter) derived from seawater would have had a much lesser role than at the Sabinas basin.

Author Contributions: E.G.-P., funding, sampling, analyses; A.C., writing, graphic design, proof editing; A.C.-C., E.H.D.-C., data processing, graphic design; L.E.G.-R., data processing, graphic design; J.L.F.-P., sampling, analyses; E.C.-A., analyses; P.M.-P., analyses; J.T.V.-R., sample preparation.

Funding: This work was funded by means of a research project from the PAPIIT program of the Universidad Nacional Autónoma de México (UNAM), number IN101113-3. Additional funding was provided by personal budgets provided by the Centro de Geociencias and the Instituto de Geología of the UNAM.

Acknowledgments: We thank Francisco Otero for his assistance at the stable isotope lab of the LANGEM.

Conflicts of Interest: To the knowledge of the authors, no conflicts of interest exist between them and any other individuals with regard to the contents of this paper.

\section{References}

1. Camprubí, A. Major metallogenic provinces and epochs of Mexico. SGA News 2009, 25, 1-21.

2. Camprubí, A. Tectonic and metallogenic history of Mexico. Soc. Econ. Geol. Spec. Publ. 2013, 17, 201-243.

3. Anonymous. La fluorita en el mundo; un presente difícil y un futuro complejo. Bol. Téc. COREMI 1998, 20-23.

4. Levresse, G.; González-Partida, E.; Tritlla, J.; Camprubí, A.; Cienfuegos-Alvarado, E.; Morales-Puente, P. Fluid origin of the world-class, carbonate-hosted Las Cuevas fluorite deposit (San Luis Potosí, Mexico). J. Geochem. Explor. 2003, 78-79, 537-543. [CrossRef]

5. Tuta, Z.H.; Sutter, J.F.; Kesler, S.E.; Ruiz, J. Geochronology of mercury, tin, and fluorite mineralization in northern Mexico. Econ. Geol. 1988, 83, 1931-1942. [CrossRef]

6. Ruiz, J.; Kesler, S.E.; Jones, L.M.; Sutter, J.F. Geology and geochemistry of the Las Cuevas fluorite deposit, San Luis Potosí, México. Econ. Geol. 1980, 75, 1200-1209. [CrossRef]

7. González-Partida, E.; Carrillo-Chavez, A.; Grimmer, J.; Pironon, J. Petroleum-rich fluid inclusions in fluorite, Purisima mine, Coahuila, Mexico. Int. Geol. Rev. 2002, 44, 755-764. [CrossRef] 
8. González-Partida, E.; Carrillo-Chavez, A.; Grimmer, J.; Pironon, J.; Mutterer, J.; Levresse, G. Geochemical evolution of mineralizing fluids at the fluorite La Encantada-Buenavista district: A Mississippi Valley Type deposit. Ore Geol. Rev. 2003, 4, 107-124. [CrossRef]

9. González-Sánchez, F.; Puente-Solís, R.; González-Partida, E.; Camprubí, A. Estratigrafía del Noreste de México y su relación con los yacimientos estratoligados de fluorita, barita, celestina y Zn-Pb. Bol. Soc. Geol. Mex. 2007, 59, 43-62.

10. González-Partida, E.; Camprubí, A.; Canet, C.; González-Sánchez, F. Fisicoquímica de salmueras e hidrocarburos en cuencas petroleras y en depósitos minerales tipo Mississippi Valley y asociados. Parte II: Ejemplos de la Cuenca de Sabinas y la Cuenca del Sureste, México. Bol. Soc. Geol. Mex. 2008, 60, $23-42$.

11. González-Sánchez, F.; Camprubí, A.; González-Partida, E.; Puente-Solís, R.; Canet, C.; Centeno-García, E.; Atudorei, V. Regional stratigraphy and distribution of epigenetic stratabound celestine, fluorite, barite, and $\mathrm{Zn}-\mathrm{Pb}$ deposits in the MVT province of Northeastern Mexico. Miner. Depos. 2009, 44, 343-361. [CrossRef]

12. González-Partida, E.; Camprubí, A.; Pironon, J.; Alfonso, M.P.; Cienfuegos-Alvarado, E.; Morales-Puente, P.A.; Canet, C.; González-Ruiz, L.E.; Díaz-Carreño, E.H. Modelo de formación de los yacimientos estratoligados de $\mathrm{Cu}$ en lechos rojos de Las Vigas (Chihuahua, México). Bol. Soc. Geol. Mex. 2017, 69, 611-635. [CrossRef]

13. Carrillo-Bravo, J. La plataforma Valles-San Luis Potosí. Bol. Asoc. Mex. Geol. Pet. 1971, 23, 61-102.

14. Carrillo-Martínez, M. Contribución al estudio geológico del macizo calcáreo El Doctor, Qro. Rev. Inst. Geol. UNAM 1981, 5, 25-29.

15. Suter, M. Cordilleran deformation along the eastern edge of the Valles-San Luis Potosi carbonate platform, Sierra Madre Oriental fold-thrust belt, east-central Mexico. Geol. Soc. Am. Bull. 1984, 95, 1387-1397. [CrossRef]

16. Fitz-Díaz, E.; Hudleston, P.; Siebenaller, L.; Kirschner, D.; Camprubí, A.; Tolson, G.; Pi Puig, T. Insights into fluid flow and water-rock interaction during deformation of carbonate sequences in the Mexican Fold-Thrust Belt. J. Struct. Geol. 2011, 33, 1237-1253. [CrossRef]

17. Omaña, L.; Alencaster, G.; Buitrón, B.E. Mid-early late Albian foraminiferal assemblage from the El Abra Formation in the El Madroño locality, eastern Valles-San Luis Potosí Platform, Mexico: Paleoenvironmental and paleobiogeographical significance. Bol. Soc. Geol. Mex. 2016, 68, 477-496. [CrossRef]

18. White, R.L. Los yacimientos de antimonio de la región de Soyatal, Estado de Querétaro. Bol. Inst. Nac. Investig. Recur. Miner. 1968, 21.

19. Wilson, B.W.; Hernández, J.P.; Meave, T.E. Un banco de calizo del Cretácico en la parte oriental del Estado de Querétaro. Bol. Soc. Geol. Mex. 1955, 18, 1-15.

20. Huspeni, J.R.; Kesler, S.E.; Ruiz, J.; Tuta, Z.; Sutter, J.F.; Jones, L.M. Petrology and geochemistry of rhyolites associated with tin mineralization in northern Mexico. Econ. Geol. 1984, 79, 87-105. [CrossRef]

21. Leroy, J.L.; Rodríguez-Ríos, R.; Dewonck, S. The topaz-bearing rhyolites from the San Luis Potosi area (Mexico): Characteristics of the lava and growth conditions of topaz. Bull. Soc. Géol. Fr. 2002, 173, 579-588. [CrossRef]

22. Nieto-Samaniego, Á.F.; Alaniz-Álvarez, S.A.; Camprubí, A. La Mesa Central: Estratigrafía, estructura y evolución tectónica cenozoica. Bol. Soc. Geol. Mex. 2005, 57, 285-318. [CrossRef]

23. Nieto-Samaniego, Á.F.; Alaniz-Álvarez, S.A.; Camprubí, A. The Central Mesa of México: Stratigraphy, structure and tectonic evolution during the Cenozoic. In Geology of México: Celebrating the Centenary of the Geological Society of México; Alaniz-Álvarez, S.A., Nieto-Samaniego, A.F., Eds.; The Geological Society of America Special Paper: Boulder, CO, USA, 2007; Volume 422, pp. 41-70.

24. Tristán-González, M.; Aguillón-Robles, A.; Barboza-Gudiño, J.R.; Torres-Hernández, J.R.; Bellon, H.; López-Doncel, R.; Rodríguez-Ríos, R.; Labarthe-Hernández, G. Geocronología y distribución espacial del vulcanismo en el Campo Volcánico de San Luis Potosí. Bol. Soc. Geol. Mex. 2009, 61, 287-303. [CrossRef]

25. Torres-Hernández, J.R.; Siebe-Grabach, C.; Aguillón-Robles, A.; Rodríguez-Ríos, R. Geocronología y características geoquímicas de un conjunto de domos riolíticos terciarios en el Campo Volcánico de San Luis Potosí, México. Bol. Soc. Geol. Mex. 2014, 66, 183-197.

26. Centeno-García, E. Mesozoic tectono-magmatic evolution of Mexico: An overview. Ore Geol. Rev. 2017, 81, 1035-1052. [CrossRef]

27. Grasel, P.C. The Reconnaissance Geology of the Salitrera Mining District, San Luis Potosí, Mexico. Master's Thesis, University of Houston, Houston, TX, USA, 1979.

28. Servicio Geológico Mexicano. Monografía Geológico-Minera del Estado de San Luis Potosí; Servicio Geológico Mexicano: Pachuca de Soto, Mexico, 2008; 273p. 
29. Olalde-Rodríguez, G. Exploración directa para la búsqueda de la continuación del cuerpo "G" tanto longitudinal N-NW como a profundidad en mina Las Cuevas, S.L.P. In Geología Económica de México: Servicio Geológico Mexicano \& Asociación de Ingenieros de Minas Metalurgistas y Geólogos de México; Clark, K.F., Salas-Pizá, G., Cubillas-Estrada, R., Eds.; Servicio Geológico Mexicano: Pachuca, Mexico, 2009; pp. 333-337.

30. Sánchez-Hernández, J.M.; Soberanes-Fragoso, B.A. Carta Geológico-Minera La Salitrera F14-C15, 1:50,000; Servicio Geológico Mexicano: Pachuca de Soto, Mexico, 2001.

31. Kemiac, M.; Cookson, J. Evolución de Paleocarst y su Relación con la Mineralización en las Minas de Fluorita El Realito y El Refugio; Unpublished Internal Report; Río Verde, S.L.P., Ed.; Servicios Industriales Peñoles: Torreon, Mexico, 1973; 30p.

32. Consejo de Recursos Minerales. Monografía Geológico-Minera del Estado de Guanajuato; Publ. M-6e; Consejo de Recursos Minerales: Guadalajara, Mexico, 1992; 136p.

33. Bodnar, R.J. Revised equation and table for determining the freezing point depression of $\mathrm{H}_{2} \mathrm{O}-\mathrm{NaCl}$ solutions. Geochim. Cosmochim. Acta 1993, 57, 683-684. [CrossRef]

34. McCrea, J.M. On the isotopic chemistry of carbonates and paleotemperature scale. J. Chem. Phys. 1950, 18, 849-857. [CrossRef]

35. Revész, K.M.; Landwehr, J.M.; Keybl, J. Measurement of $\delta^{13} \mathrm{C}$ and $\delta^{18} \mathrm{O}$ Isotopic Ratios of $\mathrm{CaCO}_{3} \mathrm{Using}$ a ThermoQuest Finnigan Gas Bench II Delta Plus XL Continuous Flow Isotope Ratio Mass Spectrometer with Application to Devils Hole Core DH-11 Calcite; Open-File Report; United States Geological Survey: Reston, VA, USA, 2001; pp. 1-257.

36. Revész, J.M.; Landwehr, J.M. $\delta^{13} \mathrm{C}$ and $\delta^{18} \mathrm{O}$ isotopic composition of $\mathrm{CaCO}_{3}$ measured by continuous flow isotope ratio mass spectrometry statistical evaluation and verification by application to Devils Hole Core DH-11 Calcite. Rapid Commun. Mass Spectrom. 2002, 16, 2102-2114. [CrossRef]

37. Minero, C.J. Sedimentation and diagenesis along an island-sheltered platform margin, El Abra Formation, Cretaceous of Mexico. In Paleokarst; James, N.P., Choquette, P.W., Eds.; Springer: New York, NY, USA, 1988; pp. 385-405.

38. Armstrong-Altrin, J.S.; Madhavaraju, J.; Sial, A.N.; Kasper-Zubillaga, J.J.; Nagarajan, R.; Flores-Castro, K.; Luna Rodríguez, J. Petrography and stable isotope geochemistry of the Cretaceous El Abra limestones (Actopan), Mexico: Implication on diagenesis. J. Geol. Soc. India 2011, 77, 349-359. [CrossRef]

39. Ferket, H. Sedimentology, Diagenesis and Fluid Flow Reconstruction in the Laramide Fold-and-Thrust Belt of Eastern Mexico (Cordoba Platform): Implications for Petroleum Exploration. Ph.D. Thesis, Katholieke Universiteit Leuveen, Leuven, Belgium, 2004; p. 309.

40. Ferket, H.; Guilhaumou, N.; Roure, F.; Swennen, R. Insights from fluid inclusions, thermal and PVT modeling for paleo-burial and thermal reconstruction of the Córdoba petroleum system (NE Mexico). Mar. Pet. Geol. 2011, 28, 936-958. [CrossRef]

41. Bordese, S.; Lira, R.; López Pinto, M.; Dalmau, J.F.; Viñas, N.A. Geología y aspectos metalogenéticos de la mineralización de fluorita-baritina del distrito Chus-Chus-Pircas Coloradas, provincias de La Rioja y Catamarca. Rev. Asoc. Geol. Argent. 2016, 73, 37-49.

42. Jemmali, N.; Carranza, E.J.M.; Zemmel, B. Isotope geochemistry of Mississippi Valley Type stratabound F-Ba-(Pb-Zn) ores of Hammam Zriba (Province of Zaghouan, NE Tunisia). Chem. Erde Geochem. 2017, 77, 477-486. [CrossRef]

43. Keim, M.F.; Walter, B.F.; Neumann, U.; Kreissl, S.; Bayerl, R.; Markl, G. Polyphase enrichment and redistribution processes in silver-rich mineral associations of the hydrothermal fluorite-barite-(Ag-Cu) Clara deposit, SW Germany. Miner. Depos. 2018, 1-20. [CrossRef]

44. Consejo de Recursos Minerales. Monografía Geológico-Minera del Estado de San Luis Potosí; Publ. M-7e; Consejo de Recursos Minerales: Guadalajara, Mexico, 1996; 219p.

45. Armienta, M.A.; Segovia, N. Arsenic and fluoride in the groundwater of Mexico. Environ. Geochem. Health 2008, 30, 345-353. [CrossRef]

46. López-Álvarez, B.; Ramos-Leal, J.A.; Moran-Ramírez, J.; Cardona Benavides, A.; Hernández García, G. Origen de la calidad del agua del acuífero colgado y su relación con los cambios de uso de suelo en el Valle de San Luis Potosí. Bol. Soc. Geol. Mex. 2013, 65, 9-26. [CrossRef] 
47. Meza-Lozano, B.; Ortiz-Pérez, M.D.; Ponce-Palomares, M.; Castillo-Gutiérrez, S.G.; Flores-Ramírez, R.; Cubillas-Tejada, A.C. Implementación y evaluación de un programa de comunicación de riesgos por exposición a flúor en la comunidad de El Fuerte, Santa María del Río, San Luis Potosí, México. Rev. Int. Contam. Ambient. 2016, 32, 87-100.

48. Grimaldo, M.; Borja-Aburto, V.H.; Ramírez, A.L.; Ponce, M.; Rosas, M.; Díaz-Barriga, F. Endemic fluorosis in San-Luis-Potosi, Mexico. I. Identification of risk-factors associated with human exposure to fluoride. Environ. Res. 1995, 68, 25-30. [CrossRef]

49. Loyola-Rodríguez, J.P.; Pozos-Guillén, A.J.; Hernández-Guerrero, J.C.; Hernández-Sierra, J.F. Fluorosis en dentición temporal en un área con hidrofluorosis endémica. Salud Pública Méx. 2000, 42, 194-200. [CrossRef]

50. Zhang, W.; Zhou, L.; Tang, H.; Li, H.; Song, W.; Xie, G. The solubility of fluorite in Na-K-Cl solutions at temperatures up to $260{ }^{\circ} \mathrm{C}$ and ionic strengths up to $4 \mathrm{~mol} / \mathrm{kg} \mathrm{H}_{2} \mathrm{O}$. Appl. Geochem. 2017, 82, 79-88. [CrossRef]

51. Pi, T.; Solé, J.; Morton-Bermea, O.; Taran, Y.; Hernández-Álvarez, E. Geoquímica de lantánidos de los yacimientos de fluorita de los distritos mineros de Taxco y Zacualpan, sur de México: Implicaciones sobre el origen y la evolución de los fluidos. Rev. Mex. Cienc. Geol. 2017, 34, 199-211. [CrossRef]

52. Magotra, R.; Namga, S.; Singh, P.; Arora, N.; Srivastava, P.K. A New Classification Scheme of Fluorite Deposits. Int. J. Geosci. 2017, 8, 599-610. [CrossRef]

53. Rodríguez-Ríos, R.; Tristán-González, M.; Aguillón-Robles, A. Estructura y geoquímica de un grupo de domos dacíticos del norponiente del campo volcánico de San Luis Potosí, México. Bol. Soc. Geol. Mex. 2013, 65, 109-122. [CrossRef]

(C) 2019 by the authors. Licensee MDPI, Basel, Switzerland. This article is an open access article distributed under the terms and conditions of the Creative Commons Attribution (CC BY) license (http://creativecommons.org/licenses/by/4.0/). 